\title{
Tissue inflammatory response to implantation of calcium hydroxide and iodoform in the back of rats
}

\author{
Resposta inflamatória tecidual da implantação de hidróxido \\ de cálcio e iodofórmio em dorso de ratos
}

\begin{abstract}
Purpose: This study evaluated the inflammatory reaction caused by the implantation of iodoform and calcium hydroxide in the back of rats. These drugs may be used as intracanal dressings to eliminate residual bacteria of the root canal system.

Methods: Twenty albinic rats (Rattus norvegicus, var Wistar) were divided into four groups: control group 1 (CG1) had normal skin; control group 2 (CG2) had wounded tissue without drugs; in groups 3 and 4, iodoform (IG) and calcium hydroxide (CHG) were inserted into the wounds, respectively. After 3,5 and 11 days, slices of the implanted areas were macroscopically and microscopically observed regarding to their qualitative and quantitative aspects.

Results: In the macroscopical analysis, the CHG showed a large area of necrosis and swelling, which progressively decreased; in the IG the presence of iodoform surrounded by normal tissue was observed. The qualitative and quantitative histological analysis showed that IG promoted a shorter delay in the inflammatory response than the CHG.

Conclusion: The inflammatory reaction for iodoform had a peak period five days after the drug insertion. By comparison, calcium hydroxide showed a very large area of necrosis that could only be partially eliminated after eleven days.
\end{abstract}

Key words: Calcium hydroxide; Endodontics; inflammation; iodoform

\section{Resumo}

Objetivo: O objetivo deste estudo foi avaliar a resposta inflamatória causada pela implantação do iodofórmio ou hidróxido de cálcio em dorso de ratos. Estas drogas podem ser usadas como curativo intracanal para eliminar bactérias residuais do sistema de canal radicular.

Metodologia: Foram utilizados 20 ratos albinos (Rattus norvegicus, var Wistar) e divididos em 4 grupos: grupo controle 1 (CG1) representado por tecido normal íntegro; grupo controle 2 (CG2) com ferida e sem medicação; nos grupos 3 e 4, lodofórmio (IG) e hidróxido de cálcio (CHG) foram, respectivamente, inseridos nas feridas. Após três, cinco e onze dias, cortes microscópicos das áreas implantadas foram observados macroscópica e microscopicamente quanto a seus aspectos qualitativos e quantitativos.

Resultados: Na análise macroscópica, o CHG mostrou uma grande área de necrose e edema, o que diminuiu progressivamente, no Gl, a presença de iodofórmio rodeada por tecido normal foi observado. A análise qualitativa e quantitativa histológica mostrou que IG promoveu um prazo mais curto na resposta inflamatória do que o CHG.

Conclusão: A reação inflamatória de iodofórmio teve um período de pico de cinco dias após a inserção de drogas. Em comparação, o hidróxido de cálcio mostrou uma grande área de necrose que só poderia ser parcialmente eliminada após onze dias.

Palavras-chave: Hidróxido de cálcio; Endodontia; inflamação; iodofórmio

\author{
Raul Capp Pallotta ${ }^{a}$ \\ Manoel Eduardo de Lima Machadob \\ Norair Salviano dos Reis ${ }^{\mathrm{C}}$ \\ Guilherme Henrique Rosa Martins d \\ Cleber Keiti Nabeshimad
}

\author{
- Graduate Course in Endodontics, São Paulo \\ General Hospital, São Paulo, SP, Brazil \\ ${ }^{b}$ Department of Restorative Dentistry, School of \\ Dentistry, University of São Paulo, São Paulo, SP, \\ Brazil \\ c Professor, Department of Biological Sciences, \\ Pontifical Catholic University, Campinas, SP, Brazil \\ d Graduate Course in Endodontics, Department of \\ Restorative Dentistry, School of Dentistry, University \\ of São Paulo, São Paulo, SP, Brazil
}




\section{Introduction}

Due to the presence of microorganisms and their by-products $(1,2)$, the root canal system infection produces a host response, which may clinically show the presence and development of periapical lesions $(3,4)$. These microorganisms are a constant source of aggression and demand an inflammatory response (5). Eliminating this micro flora makes the inflammatory process in progressing up to the periapical repair. Traditional endodontics is unable to eliminate the microorganisms and might require a complementary therapy $(5,6)$.

Root canal preparation must have its disinfection complemented by drugs with effective antibacterial action and the ability to stimulate periapical repair as well (6). Some drugs can be used for this purpose. The most widely used is calcium hydroxide (7-10). Its main mechanism is the establishment of an alkaline $\mathrm{pH}$ of the environment, where few microorganisms are able to survive (7). Another drug used to improve the antibacterial activity is iodoform, which has been used successfully as a medicament and filling paste for many years (10-13). Iodoform seems to stimulate immunological response by promoting the growth of granulation tissue, and thus accelerating the healing process (14).

These two drugs have a high rate of success in the treatment of periapical lesions $(8,11,13,15)$, and show similar antibacterial activity in in vitro evaluations (10). Nevertheless, antibacterial evaluations showed that not only iodoform has a high performance alone (10), but it increases the antibacterial activity of calcium hydroxide when they are associated (11). In addition, the action of these drugs might be influenced by the interaction with dental tissues and contamination characteristics $(16,17)$. Besides the importance of the direct action of medicaments, it is possible to assure that these drugs must create inappropriate conditions for bacterial development.

Whenever the drugs are inserted into the canal, a direct contact between the drugs and the tissue in the apical area might happen. This contact of the dugs with connective tissue, whether accidental or not, has proved to be effective in eliminating the contamination $(10,11,15)$. However, in this case, the citotoxicity of these drugs must be assessed. Clinically, calcium hydroxide is effective, although it presents a high number of flare-ups (18) once accidentally extravasated to the periapical region, which is not usually observed in the use of iodoform (12).

To justify this clinical finding, tissue reactions and interactions might be considered in order to understand the behavior of these drugs when used as intracanal dressing. Above all, the aim of this study was to evaluate the quantitative and qualitative inflammatory reaction to iodoform and calcium hydroxide when these drugs were inserted in the back of rats, by means of macroscopical observation and optical microscope analysis.

\section{Methods}

After approval by the institutional ethics committee, 20 male albinic rats (Rattus norvegicus, Wistar), weighing
$300 \pm 120 \mathrm{~g}$, were selected from the PUCCAMP Research Centre, in Campinas, SP, Brazil. The method used for evaluation was the qualitative and quantitative histological tissues' reaction analysis to the drugs on the back of rats $(19,20)$.

The animals were randomly distributed into four groups. Control group 1 (CGI) corresponded to normal skin without any treatment; in control group 2 (CGII) two incisions were made, one on each side until the subcutaneous tissue was reached. Subsequently, the wound was exposed until it got to the muscular tissue and the skin was sutured. In the other groups drugs were mixed to the concentration clinically used and inserted into wound. In group 3 (CHG), calcium hydroxide was associated with polyethylene glycol 1400 and in group 4 (IG) iodoform was associated with Carbowax $^{\circledR}$.

The macroscopic characteristics of the wounds were analyzed after the experimental periods ( 3,5 and 11 days), due to the presence of necrosis, exudate and/or swelling.

Three days after the drug insertion, five animals from each group had one of the wounds removed. The excised tissues were fixed for, at least, $24 \mathrm{~h}$ in BOUIN $(85 \mathrm{~mL}$ of saturated picric acid, $15 \mathrm{~mL}$ of formaldehyde and $5 \mathrm{~mL}$ of Glacial Acetic Acid,). New tissue samples were obtained from the other wounds after 5 and 11 days. For each of the experimental groups, 15 samples were obtained.

The fragments were then prepared to be histologically processed. The slices were stained with either HematoxylinEosin (H-E) or Mason Trichrome. For each group, five glass slides were used and, from each one of them, three microscopic fields were randomly chosen and analyzed. The slices were microscopically evaluated concerning their qualitative and quantitative aspects. The quantitative analysis comprised the observation, of pictures of histological fields. Digital photomicrographs images were taken and transferred to the computer. The most representative structure of each grid point was verified, i.e., for each field, one hundred structures were recorded. A total magnification of $400 \mathrm{X}$ was used to observe the structures. Data were statistically analyzed by using ANOVA and Tukey's test $(\alpha=0.05)$.

\section{Results}

\section{Macroscopical evaluation}

In the macroscopic evaluation of the wound, a normal tissue was observed in the control group (CGII) and also in the rats of the iodoform group (IG) after 3 days; in contrast, the group treated with calcium hydroxide (CHG) showed an area of necrosis in the same period. After 5 days, normal skin could be observed in the back of the rats in the IG and CGII; in the CHG a large swelling area was observed. On the 11th day, the IG showed the presence of iodoform in a subcutaneous tissue with normal aspect, which was not seen in the CHG where the swelling area was maintained in most of the animals. 


\section{Microscopical evaluation}

\section{Qualitative analysis}

\section{- 3 days}

In the CGII (Fig. 1A) a reepithelization of the wound was observed; in the dermitis, a cell infiltrate was seen with the predominance of macrophages besides the presence of neutrophils and fibroblasts. Fat and muscle cells are in normal conditions. At the border of the wound a significant number of collagen fibers were seen.

In the IG (Fig. 1B) it was observed an epithelium with a higher number of cell layers at the border of the wound, which were separated by fibrin. In the dermitis it was possible to see a small area of necrosis restricted to the wound, surrounded by inflammatory cells, most of them macrophages, but other phagocytes were observed such as giant cells. There was a loss of fat cells inherent to the action of iodine and the muscle tissue was intact. Collagen fibers were observed surrounding the wound.

The CHG (Fig. 1C), however, showed the breakage of the epithelium tissue, without signs of reconstitution of the tissue. Dermitis presents a very large area of necrosis, where fat cells are presented as empty spaces and some muscle cells are in degeneration. A fibrin crust was usually observed with a great number of dead cells. Surrounding the wound, some macrophages were present and a few were observed inside the injured area. Collagen fibers were observed under the edges of the wound.

\section{- 5 days}

After 5 days, the control group (Fig. 2A) showed the new epithelization of the wound; the dermitis presented coagulated plasma surrounded by an inflammatory infiltrate with macrophages and some giant cells just below the epithelium, followed by a great number of fibroblasts. Inside it, some neutrophils were seen. As to collagen fibers, there was a small area of fibrin below the epithelium with collagen fibers all over the wound.

The IG (Fig. 2B) showed, on the edges of the wound, epithelial cells that seemed to be multiplying or squeezing towards the wound area over the fibrin layers, which appeared to be smaller than the one found after three days. Just below that, in the dermitis, a severe inflammatory infiltrate was seen with a great number of macrophages and a new vascularization in an area where fat cell destruction was restricted to the place the medication was inserted. Collagen fibers were seen at the base of the lesion where the infiltrate is smaller and some other few fibers could be seen inside the lesion

In the CHG, a very large area of necrosis was seen in the epithelium and in the dermitis (Fig. 2C). There were a high number of giant cells and a fibrin net at the border of the lesion around this area. Just below that, inside the muscle tissue, some defense cells, such as macrophages, were seen. There were no visible fat cells. Several collagen fibers were found on the base of the wound.
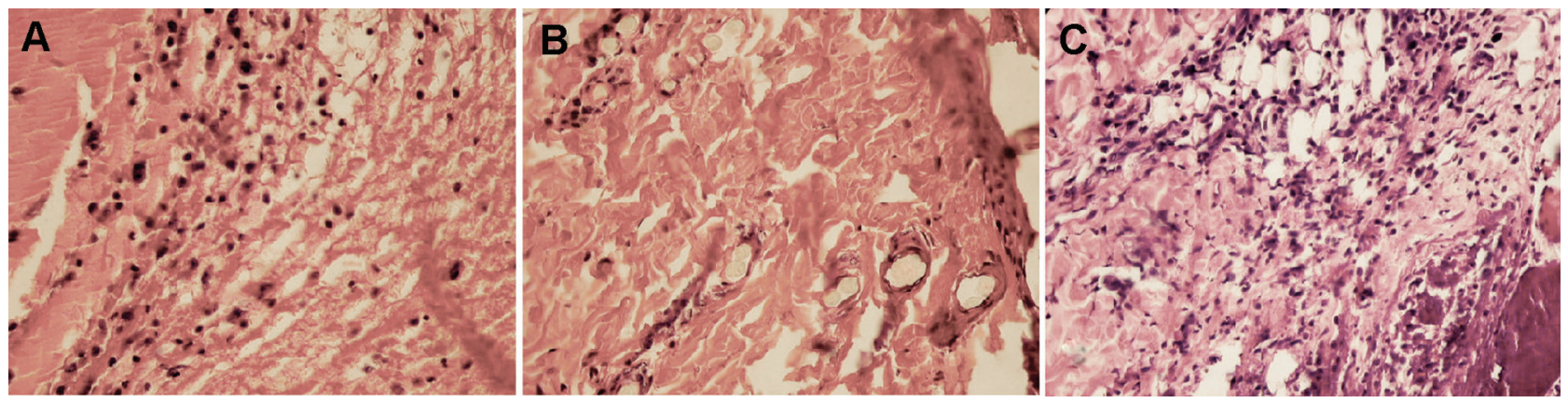

Fig. 1. Three days after drug insertion: (A) control group (GCII), great amount of inflammatory cells; (B) - iodoform (IG), collagen fibers and a sparse inflammatory infiltrate; (C) - calcium hydroxide (CHG), area of necrosis and dead cells. (Original Magnification: $400 \times)$.
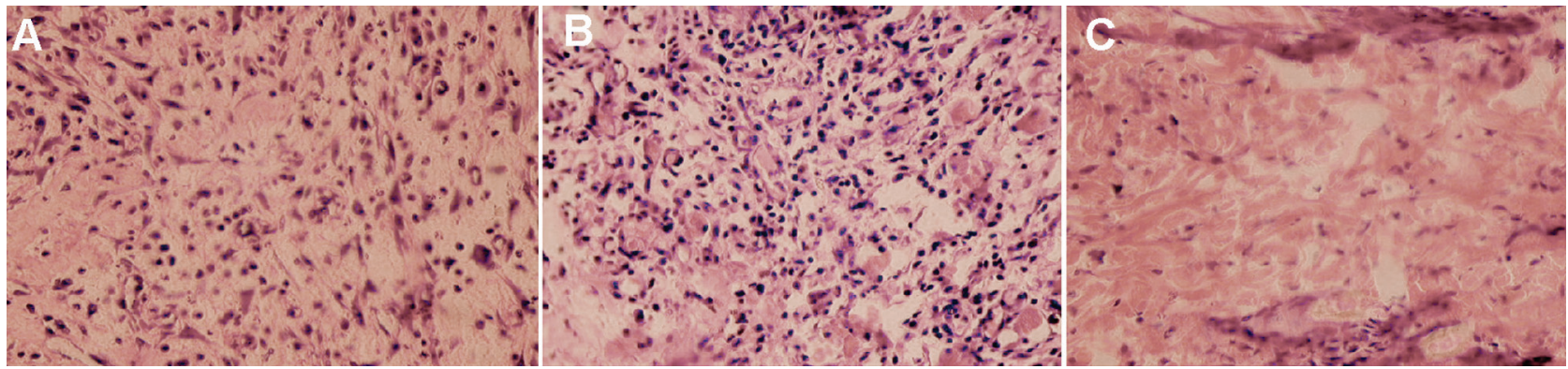

Fig. 2. Five days after drug insertion: (A) control group (GCII), several inflammatory cells, specially macrophages and giant cells and some fibroblasts; (B) iodoform (IG), neovascularization and the presence of inflammatory cells; (C) calcium hydroxide (CHG), area of necrosis and the beginning of the inflammatory action and the presence of some giant cells. (Original Magnification: $400 \times$ ). 


\section{- 11 days}

After eleven days, CGII (Fig. 3A) showed an intact epithelium with the formation of keratin. In the dermitis, a small infiltrate was observed with a great number of fibroblasts, sparse giant cells and a small amount of collagen fibers was present besides the rest of the tissue where a great number of collagen fibers was seen.

After the experimental period the IG (Fig. 3B) showed an intact epithelium and dermitis, where several collagen fibers were observed and the wound was surrounded by collagen fibers. A great number of macrophages, and giant cells were around a very small area of necrosis. The fat tissue was normal just below these fibers.

Additionally, the CHG (Fig. 3C) showed the epithelium in an early repair stage. The edges were still separated by a fibrin crust. Close to the edges, a large inflammatory infiltrate was seen with a great number of macrophages, fibroblasts and giant cells. Fat and muscle cells were reorganizing themselves, although there was still a large area of empty spaces in the fat tissue. Collagen fibers surrounded the lesion and also a huge new vascularization was observed.

\section{Quantitative analysis}

The quantitative analysis evaluated the number of the studied structures on the histological slices.

\section{- 3 days}

After three days, the quantitative analysis (Fig. 4) showed a significant difference between the groups, except for epithelial cells, which were not comprised in this study. The IG presented a high number of collagen fibers and vessels. The number of points with collagen fibers in IG was only similar to those found in CGI (normal skin), and in both groups the presence of these fibers was significantly higher than the others. Also, in the IG, vessels were present in a higher number than in all the other groups. Additionally, the $\mathrm{CHG}$ presented a number of neutrophils and fibroblasts significantly higher, and a presence of other structures similar to the CGII; however, in the CHG these other structures were usually empty spaces and in CGII they were fibrin areas.

There were fewer lymphocytes in the IG than in CGII and in the CHG and CGI the presence of this cell was not observed. As to macrophages, they were in a lower number in the iodoform group and similar in the others.

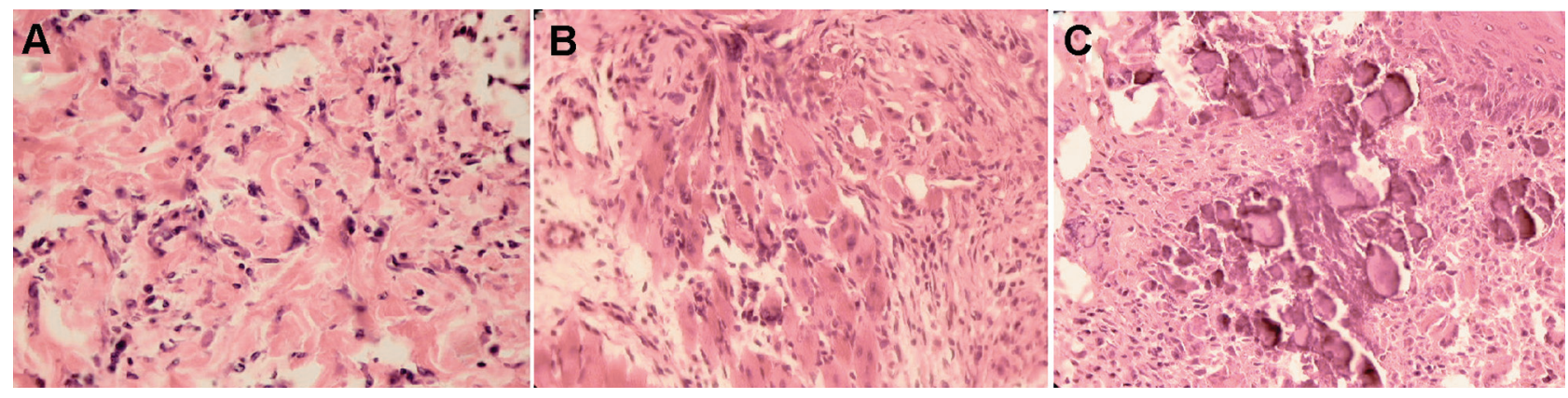

Fig. 3. Eleven days after drug insertion: (A) control group (GCII), great amount of collagen fibers and fibroblasts; (B) iodoform $(\mathrm{IG})$, several inflammatory cells and fibroblasts; (C) calcium hydroxide (CHG), reorganization of the tissue, besides the presence of calcium hydroxide. (Original Magnification: 400×).

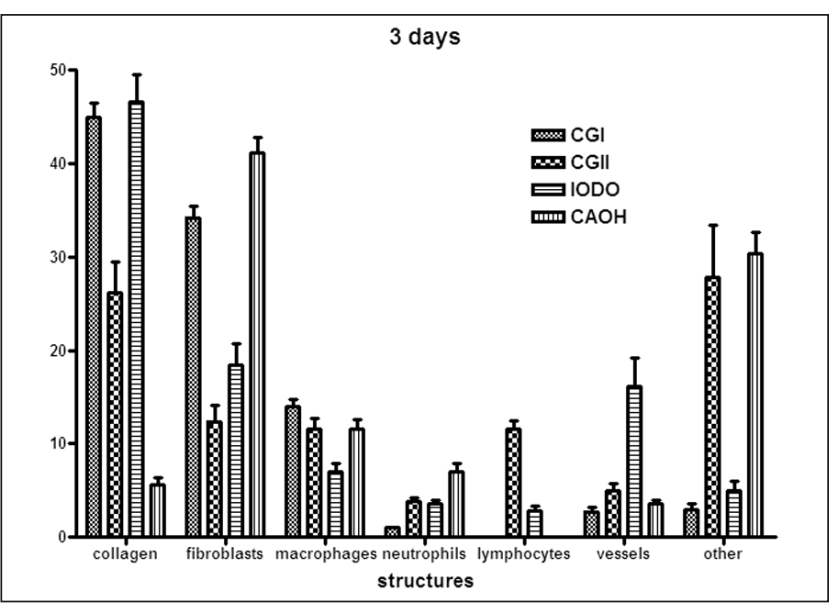

Fig. 4. Graphic of the percentage of cells and structures observed in the quantitative histological analysis after three days the wound was made and the drug was inserted (mean values and standard deviation).

\section{- 5 days}

After five days there were dramatic differences between the reaction to iodoform (IG) and to calcium hydroxide (CHG) (Fig. 5). The number of macrophages, neutrophils, vessels and lymphocytes was higher in the iodoform group than in all the other groups, whereas in the other groups the presence of these structures was similar. In the calcium hydroxide group, it was observed that the number of other structures was higher than in all other groups and there was an amount of fibroblasts similar to normal skin and higher than that of the other groups. Also, treated groups presented a number of collagen fibers lower than the normal skin and control wound groups.

\section{- 11 days}

At last, after eleven days (Fig. 6), it was seen that the complete repair process was being carried out. Treated groups showed a similar number of macrophages, fibroblasts 
and neutrophils. Fibroblasts and neutrophils were in a higher number than in groups CGI and CGII. Macrophages, on the other hand, were present in a number similar to that of the control wound, but there were fewer of these cells in normal skin.

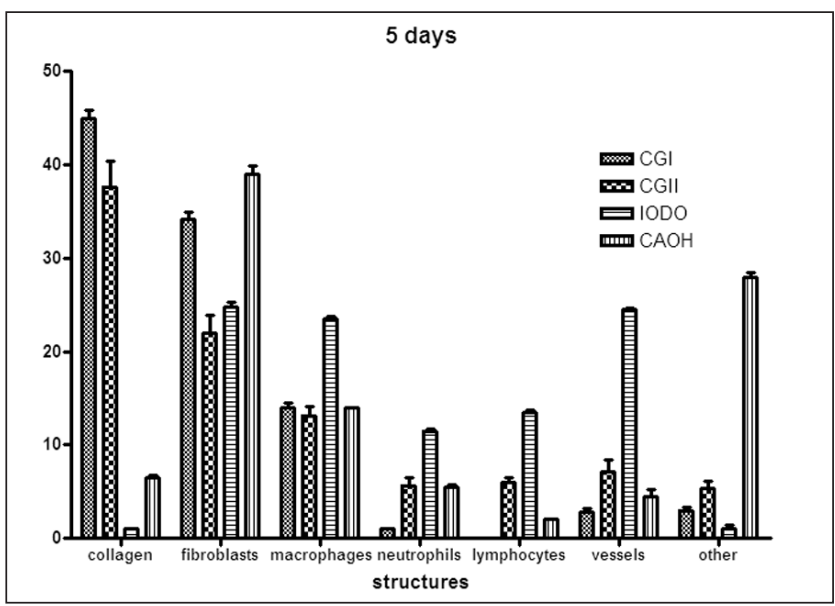

Fig. 5. Graphic of the percentage of cells and structures observed in the quantitative histological analysis after five days the wound was made and the drug was inserted (mean values and standard deviation).

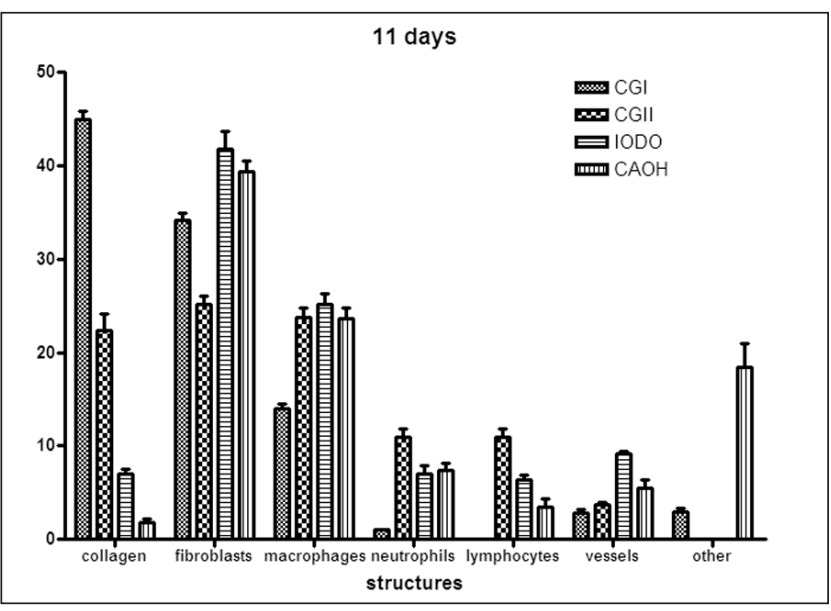

Fig. 6. Graphic of the presence percentage of cells and structures observed in the quantitative histological analysis after eleven days the wound was made and the drug was inserted (mean values and standard deviation).

The IG presented a higher number of vessels than all other groups, and also a number of lymphocytes higher than the $\mathrm{CHG}$, both lower than the control wound. Calcium hydroxide showed a higher number of other structures than all other groups. Additionally, treated groups still had fewer collagen fibers than the control groups of normal skin and control wound.

\section{Discussion}

The presence and persistence of microorganisms inside the root canal provokes a periapical response of the host, which may be clinically observed as periapical alterations (1-4) In these cases, endodontic therapy is necessary to clean and disinfect the source of microorganisms: the root canal $(5,6,9)$. Due to bacterial characteristics of contamination and resistance $(13,16,17)$, as well as root canal anatomic variations, the use of an intracanal medication might be necessary for an additional decontamination $(7,8,11)$. This medication may act by eliminating the contamination and/ or creating unsuitable conditions for the development and establishment of these microorganisms and by stimulating the host inflammatory response in order to eliminate the aggression factors $(7-9,11,13,15)$. In this investigation, iodoform and calcium hydroxide were inserted in the back of rats, so that the action of these drugs on tissue could be investigated $(19,20)$.

In this study, the performance of iodoform (IG) was significantly better than the one of calcium hydroxide (CHG). Macroscopic analysis allowed the visualization of an apparent normal tissue in the IG, whereas the CHG usually presents an area of necrosis and/or swelling. The difference between the drugs' behavior is much more noticeable in the histological observation. The CHG showed a longer delay in the repair process, with large necrotic areas spreading to the muscle tissue. In this group, the repair could only be seen after eleven days. This period is close to the peak of the drug action in tissue and in bacteria (9). In the IG, the area of necrosis was restricted to the wound area, besides the loss of fat cells, which is an inherent action of iodine on fat (14). Additionally, phagocytic cells were surrounding the lesion, showing the activation of the inflammatory reaction. It could be noticed that the $\mathrm{CHG}$ was always one experimental period behind the IG and this group was one experimental period behind the control wound, which means that repair in the IG was faster than in the CHG.

The results found for the quantitative analysis could relate the histological and clinical findings $(10,12,13,15,18)$. The presence of inflammatory cells (macrophages, lymphocytes and neutrophils) was higher in the control wound after three days and similar after five days. The IG promoted a neovascularization, which was seen in all experimental periods, with a peak on the $5^{\text {th }}$ day. A great number of neutrophils and lymphocytes could be observed as well; and the number of macrophages also increased, and this was only seen in the IG, probably because of the great antigenicity of iodoform $(10,12,14)$. In the $\mathrm{CHG}$, there were few inflammatory cells; a great number could only be seen eleven days after the medication was inserted, in the repair stage, according to what has been found in other investigations $(14,20)$.

All in all, the inflammatory action of iodoform in this study had a peak period of five days after the drug insertion and the inflammatory process tended to establish a chronification after eleven days. On the other hand, calcium hydroxide presented an acute process during all the experimental period. So, the chronification and the beginning of the repair process should take place in a shorter period for iodoform than for calcium hydroxide. 
The number of fields with fibroblasts was almost the same for the $\mathrm{CHG}$ in all evaluation periods. Although the fibers synthesization is performed by fibroblasts which process depends on calcium, the presence of these fibers had no apparent correlation, in this investigation, with the calcium that is supposed to be released by calcium hydroxide. The relation between fibroblasts and collagen fibers in the iodoform group showed an increasing number of cells during all the experimental period and a decrease in the number of collagen fibers between the first two periods. This could be explained by the delay in the inflammatory reaction provoked by this drug, which is in agreement with other studies $(10,12,14)$.

Calcium hydroxide produced a large tissue necrosis, which could justify the occasional clinical findings of pain and swelling when the periapical extravasation of the drug occurs (19). On the other hand, iodoform shows a slow and continuous release of iodine, and an interaction with bacteria, which leads to the stimulation of the inflammatory reaction because of its antigenicity, i.e., iodoform acts as a foreign body and develops an immunological reaction $(11,12)$. So iodoform showed higher efficiency with an inevitable, but shorter delay in the repair, according to clinical findings $(10,18)$.

Clinically, the type of lesion and consequently its physical characteristics should be considered to confirm these results. The presence of exudate in a periapical abscess or the chronical inflammatory tissue in an apical granuloma makes the reaction to these drugs different. This is due to the direct contact with the tissue and the available space to this drug fulfill. The occasional extravasation of the drug should be a real concern to endodontists, whether accidentally, or intentionally. Whenever one of these situations occurs, iodoform seems to be better accepted. Other studies should be carried out in order to recognize the inflammatory mediators involved and/or inhibited in the action of these and other drugs in the periapical area.

\section{References}

1. Seltzer S, Farber PA. Microbiologic factors in Endodontology. Oral Surg Oral Med Oral Pathol 1994;78:634-45.

2. Sundquist G. Taxonomy, ecology, and pathogenicity of the roo canal flora. Oral Surg Oral Med Oral Pathol 1994;78:522-30.

3. Jontell M, Okiii T, Dahlgren U, Bergenholtz G. Immune defense mechanisms of the dental pulp. Crit Rev Oral Biol Med 1998;9:179-200.

4. Tronstad L, Barnett F, Riso K, Slots J. Extraradicular endodontic infections. Endod Dent Traumatol 1987;3:86-90.

5. Nair PN. On the causes of persistent apical periodontitis: a review. Int Endod J 2006;39:249-81.

6. Sakamoto M, Siqueira JR JF, Rocas IN, Benno Y. Bacterial reduction and persistence after endodontic treatment procedures. Oral Microbiol Immunol 2007;22:19-23.

7. Siqueira Jr JF, Lopes HP. Mechanisms of antimicrobial activity of calcium hydroxide: a critical review. Int Endod J 1999;32:361-9.

8. Dammaschke T, Schneider U, Stratmann U, Yoo JM, Schäfer E. Effect of root canal dressings on the regeneration of inflamed periapical tissue. Acta Odontol Scand 2005;63:143-52.

9. Tang G, Samaranayake LP, Yip HK. Molecular evaluation of residual endodontic microorganisms after instrumentation, irrigation and medication with either calcium hydroxide or Septomixine. Oral Dis 2004; 10:389-97

10. Pallotta RC, Ribeiro MS, Machado ME. Determination of the minimum inhibitory concentration of four medicaments used as intracanal medication. Aust Endod J 2007;33:107-11.

11. Cwikla SJ, Bélanger $M$, Giguère $S$, Progulske-Fox A, Vertucci FJ. Dentinal tubule disinfection using three calcium hydroxide formulations. J Endod 2005;31:50-2.
12. Manisali Y, Yücel T, Erisen R. Overfiling of the root. A case report. Oral Surg Oral Med Oral Pathol 1989;68:773-5.

13. Trusewaicz M, Buczkowska-Radlinska J, Giedrys-Kalemnba S. The effectiveness of some methods in eliminating bacteria from the root canal of a tooth with chronic apical periodontitis. Ann Acad Med Stetin 2005;51:43-8.

14. Ortega KL, Rezende NP, Araujo NS, Magalhaes MH. Effect of a topical antimicrobial paste on healing after extraction of molars in HIV positive patients: randomised controlled clinical trial. Br J Oral Maxillofac Surg 2007;45:27-9.

15. Abdullah M, NG YL, Gulabivala K, Moles DR, Spratt DA. Susceptibilties of two Enterococcus faecalis phenotypes to root canal medications. J Endod 2005;31:30-6.

16. Distel, JW, Hatton JF, Gillespie MJ. Biofilm formation in medicated root canals. J Endod 2002;28:689-93.

17. Haapasalo HK, Sirén EK, Waltimo TM, Ørstavik D, Haapasalo MP. Inactivation of local root canal medicaments by dentine: an in vitro study. Int Endod J 2000;33:126-31.

18. De Moor RJG, De Witte MJ. Periapical lesions accidentally filled with calcium hydroxide. Int Endod J 2002;35:946-58.

19. Kaplan AE, Ormaechea MF, Picca M, Canzobre MC, Ubios AM Rheological properties and biocompatibility of endodontic sealers. Int Endod J 2003;36:527-32.

20. Zmener O, Guglielmotti MB, Cabrini RL Biocompatibility of two calcium hydroxide-based endodontic sealers: a quantitative study in the subcutaneous connective tissue of the rat. J Endod 1988; 14:229-35. 